\title{
Learning by Teaching, Why Not?
}

\author{
Sri Damayanti ${ }^{* 1}$, Sri Hastuty ${ }^{2}$, Juwita Crestiani ${ }^{3}$, Alim Surya \\ Saruman ${ }^{4}$, Irwan ${ }^{5}$
}

\author{
I, 2, 3, 4 Universitas Cokroaminoto Palopo \\ ${ }^{5}$ SMA Negeri 6 Palopo \\ *yanthie_uncok@ymail.com
}

\begin{abstract}
Lesson Study for Learning Community was held by applying Magang Based Lesson Study at Universitas Cokroaminoto Palopo. There were ten Students collaborated with 4 lecturers and 4 teachers. Those teachers are the teachers at SMP Negeri I Palopo, SMP Negeri 2 Palopo, SMP Cokroaminoto Palopo, and a teacher at SMA Negeri 6 Palopo. This paper aimed is describing the students' activities in learning by teaching and how they prepare their class. The research question of this paper is what are the students' activities in preparing their class? How do the students' prepare their class? What Lesson learned found in Magang Based Lesson Study? In answering the research question, the researcher conducted a research in a year by participating in learning community. Although this research has not finished yet, she describes that the students who conducted Magang prepared their class by learning how do their students learn. After that, they discussed it by collaborating with lecturers at Universitas Cokroaminoto Palopo. In doing teaching in classroom, the rest of the students observed the students' way in learning. It is about when the students start to focus on studying, how they learned collaboratively with their groups.
\end{abstract}

Keywords: learning; collaborative learning; learning community

\section{Introduction}

Learning is an activity to have a positive changes. Theory of learning that is stated by some experts in some point of views. The behaviorism stated about stimuli-response. The position of the one who learn is the passive position. It is different with the cognitivism which is stated that the learner process the information and knowledge through his/her effort to have relation between new knowledge and their previous knowledge. This model focus on how the information is processed. So, the concept of learning is about environment is the place where the learners take the knowledge, while the constructivism stated that learning is not only about the system of fact or concepts which must be taken and remembered, but also to be constructed and applied in real life. So, based on the three above, Universitas Cokroaminoto Palopo has a concept of constructing knowledge in its curriculum, one of them is Magang III subject.

Damayanti (2017) figured on her research that the practice of Lesson Study at Universitas Cokroaminoto Palopo mostly used Plan-do-see cycle. The lecturers and the teacher began their teaching from plan until see phase. It shows us that the collaborated schools in Palopo are ready as the plot schools in Magang III based Lesson Study conducted by Faculty of Teacher Training and Education at Universitas Cokroaminoto Palopo.

The objective of Magang III is hopefully the students can achieve in having four competence such as pedagogic, professional, social, self-esteem. In Magang III, the students 
apply their knowledge based on their capability, act as a professional teacher, to have relationship with students, teachers, and staffs. Moreover, they are hoped to have a good personality such as disciplinary, honesty, positive thinking, etc. The students of Magang III are helped by the guided lecturers and guided teachers. So, in Magang III, there is important point which is needed to build, the collaboration between teachers, lecturers, and students. The lecturers is not only facilitate the students administrative in schools, but also have a positive contribution to build the students self-confidence to learn how to be a teacher. So, the concept of relationship between teacher, lecturers, and students adapted from the concept in Japan called Jugyokenkyuu. It is applied by Universitas Cokroaminoto Palopo in one of subject at Faculty of Teacher Training an Education which is called Magang III based Lesson Study.

The concept of learning by teaching in Lesson Study hopes there will be positive relationship between lecturers, teachers, and students. Here, the pre-service teachers will learn more from the students. They learn more about how to construct their instruction in classroom to facilitate the students to learn, the learn how to facilitate media of learning to all the students, they learn how to design worksheet to facilitate all the students to learn, etc. The students are not only act as a teacher to stand up in front of the pupils, but also they learn though the pupils fails in understanding lessons. These pre-service teachers do some dialogues and discussion with teachers at schools and the lecturers. They plan the lesson design detailly. Others, the lecturers, the other pre-service teacher, the teachers observe the students reaction toward the initiation from the pre-service teacher. The figure I below shows us about the concept of activity in Lesson Study by Lewis, Perry, \& Murata (2008).

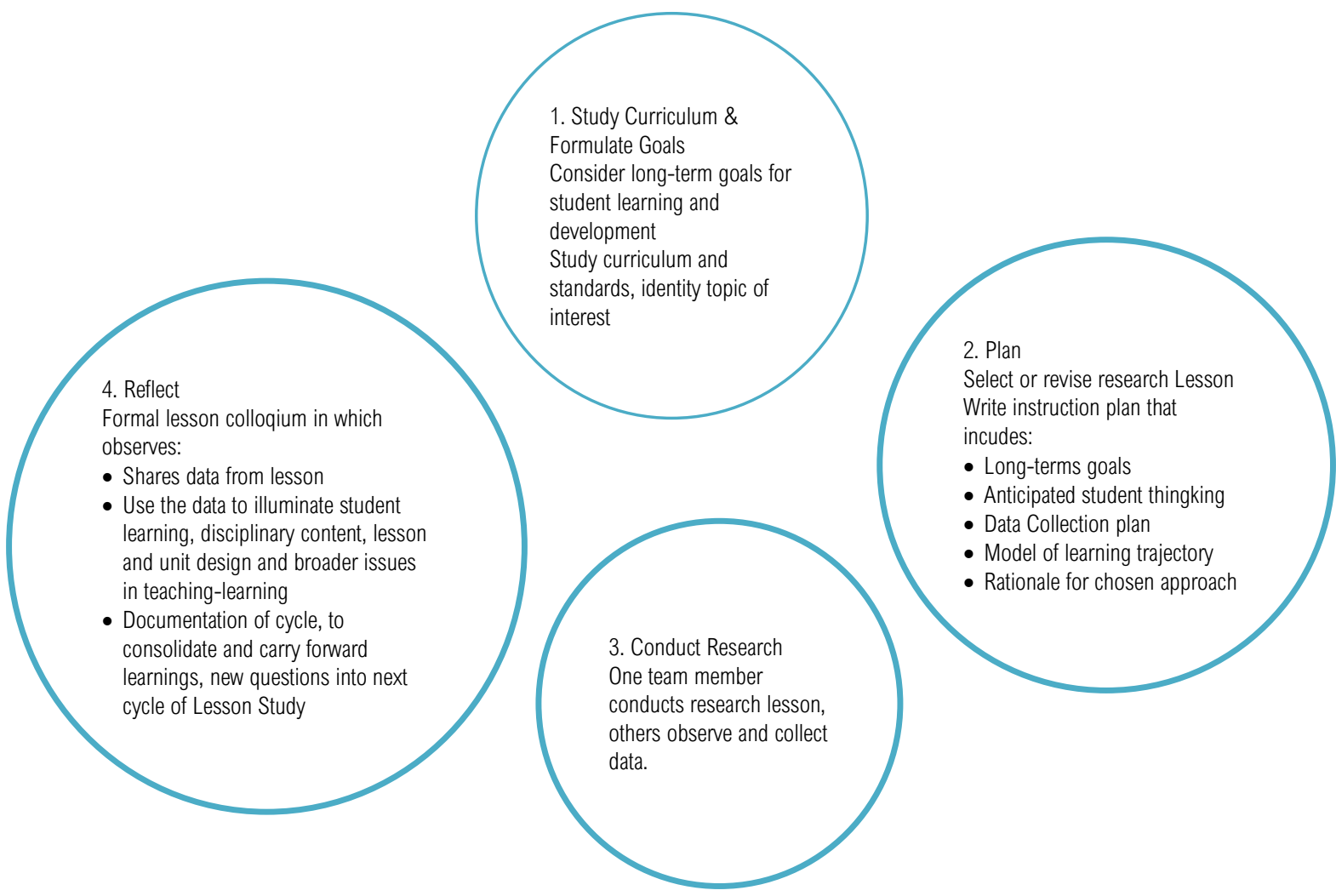

Figure I. The Concept of Lesson Study Activity 
Lewis, Perry, \& Murata (2008) graphically depicts the lesson study cycle. Lesson Study shares certain characteristics with various North American professional development approach. For example, lesson study shares with analysis of students work a focus on evidence of student thinking, and it shares with video cases the analysis of actual instructions. However, no other approach has exactly the constellation of characteristics found in Figure I, with a live classroom lesson as the centerpiece of study. Brown (2000) states that learning is:

I. Learning is acquisition of "getting"

2. Learning is retention of information or skill

3. Retention implies storage systems, memory, cognitive organization

4. Learning involves active, conscious focus on and acting upon events outside or inside the organism.

5. Learning is relatively permanent but subject to forgetting

6. Learning involves some form of practice, perhaps reinforce practice.

7. Learning is a change in behavior.

While teaching is showing or helping someone to learn how to do something, giving instruction, giving in the study of something, providing with knowledge, causing to know or understand. So, teaching cannot be defined apart from learning.

\section{Method}

This article is a qualitative reseach focused on revitalization of Magang III at Faculty of Teacher Training and Education in Universitas Cokroaminoto Palopo through Lesson Study activities. The samples are 10 students from 4 schools, 4 teachers and four lecturers. This research will be conducted in one year in January - December 2018. The procedures of collecting data such as, socializing, Magang based Lesson Study, giving questionnaire and interview, follow up the result of questionnaire and interviews. If the knowledge of concept of Lesson Study known by the pre-service students and teachers is less than $50 \%$, the researcher will plan pre-service student will teach again.

\section{Preliminary Findings}

\section{The Students (Pre-Service Students) Activities in preparing the class}

I. Consult with the Guide-Teacher

2. Do some coaching with the guide-lecturer

3. Discussing some topics, how to prepare some questions to the students, how to arrange sentences, how to group the students.

\section{How The Pre-Service Students Prepare the Class}

Before preparing the class, they prepared their selves first. They do some microteaching or practice stand up in the classroom in front of the lecturers.

\section{The Lesson Learned from Magang Based Lesson Study}

Caring is one of solution to help the fail student. One of fail students in Magang III caused by her disability in building self-confidence, as a result she cannot construct instruction in front of the classroom. Moreover, she has disability in writing well by hand-writing. She is helped by her lecturers and teacher to build self-confidence by the care. So, we can see the 
relationship between learning and teaching. Although they are different in function, but both of them cannot be separated each other. It can be seen in Figure 2 below.

Teaching

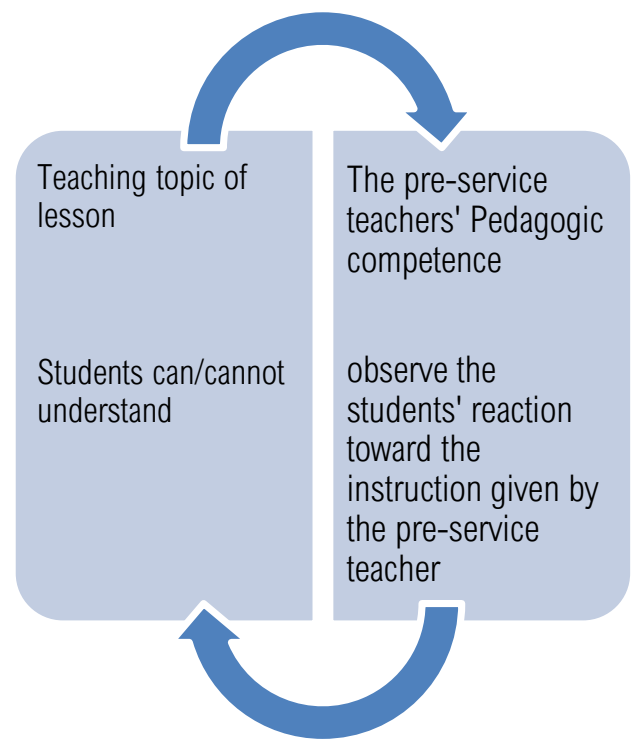

Learning

Teaching

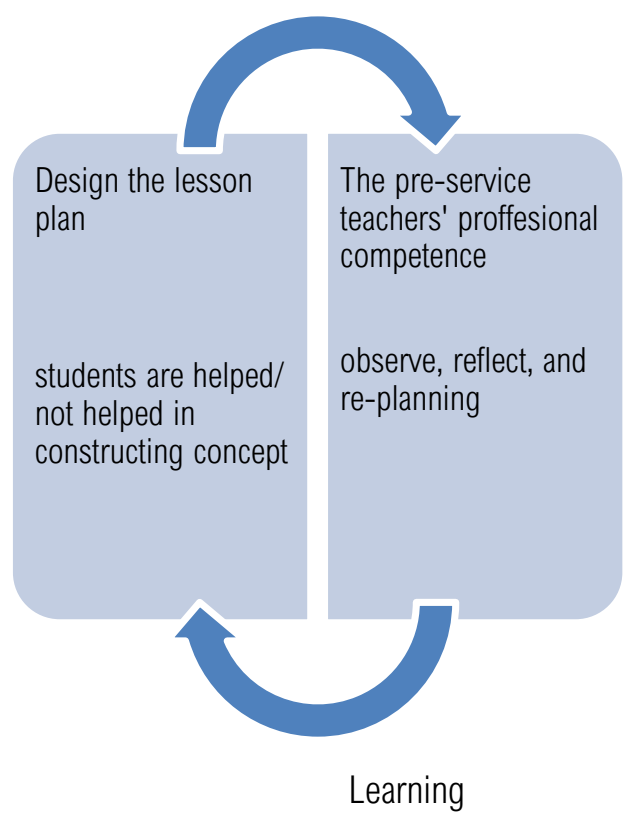

Teaching

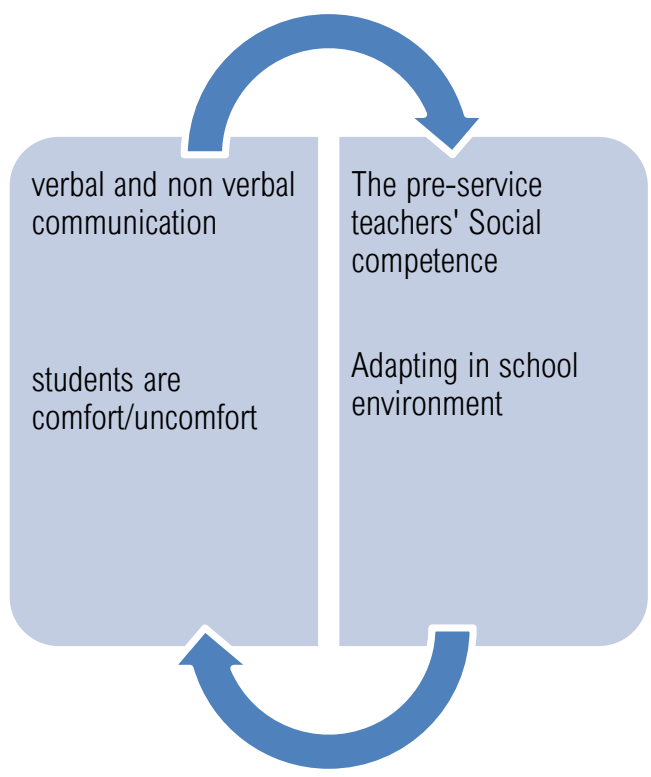

Learning

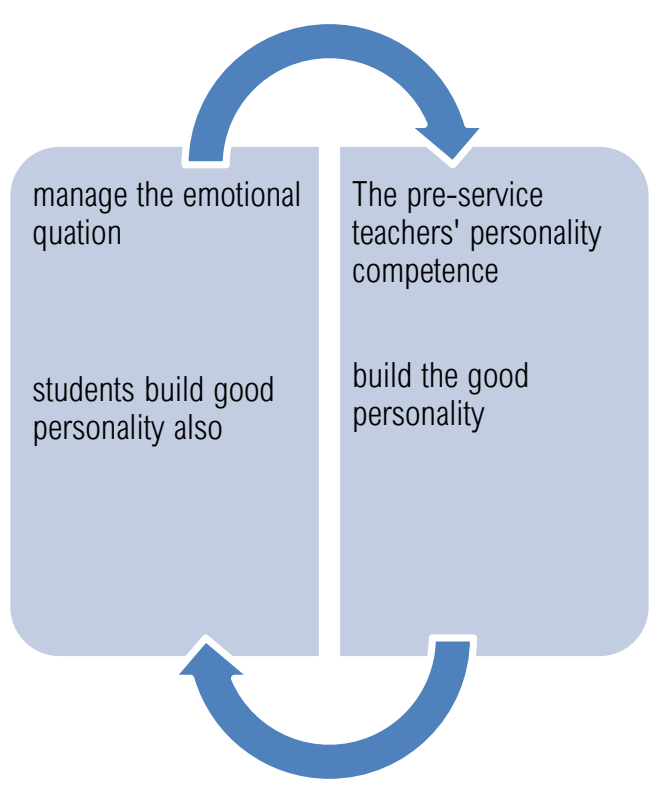

Learning

Figure 2. The concept of Learning by teaching in Magang III based Lesson Study 
The Process of Magang III based lesson study which build the collaborative activities between teacher, students, and lecturers shown as follow:

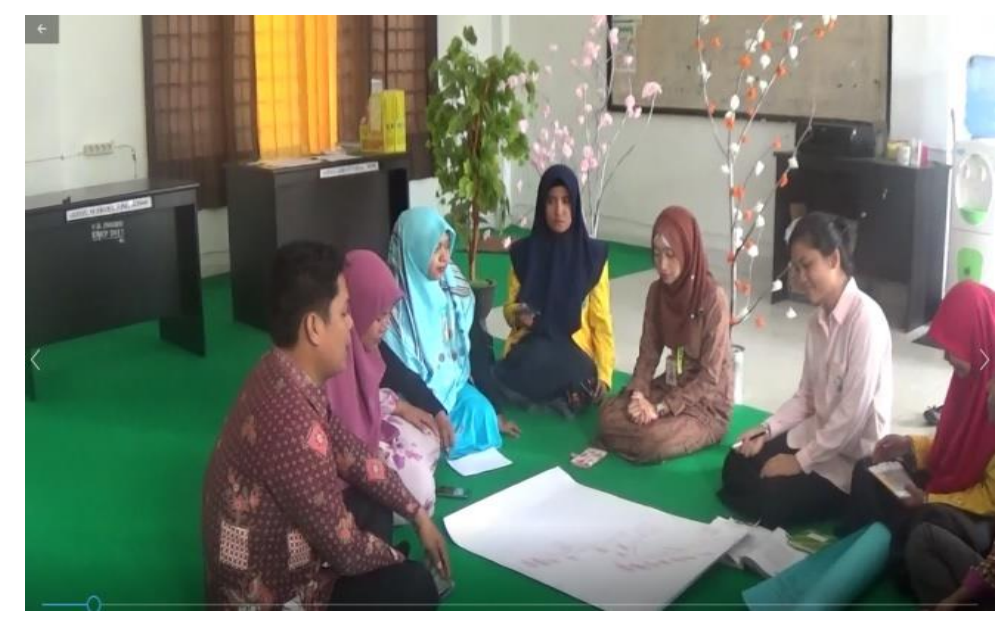

Plan: pre-service teacher, students, lecturers discuss about the preparation before teaching

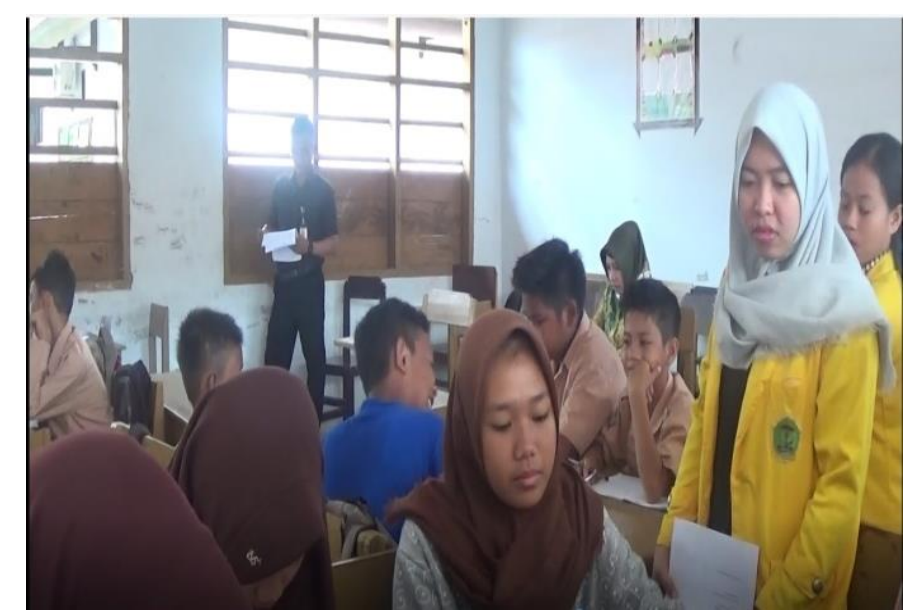

Open class: The lecturer and pre-service students observed how the students learn

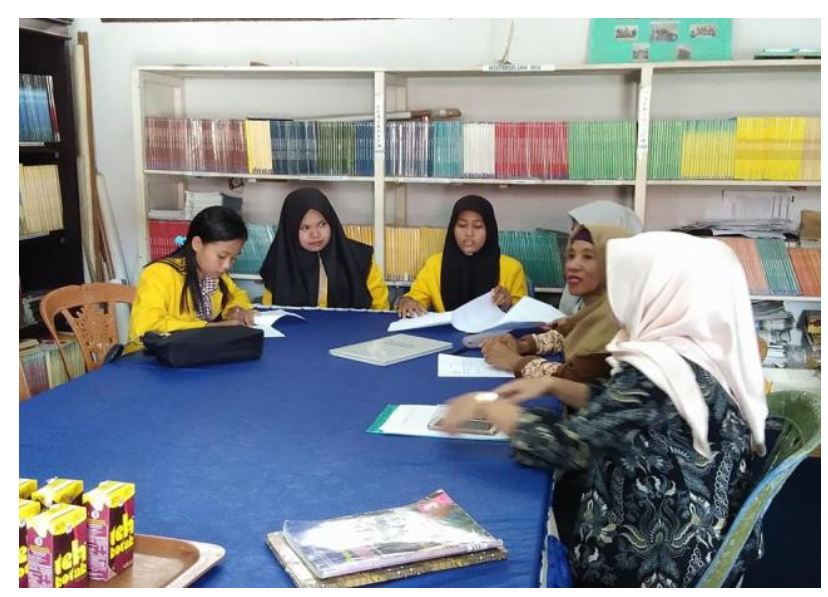

Reflection : discussing about what the students done or reaction from the instruction from the pre-service teacher 


\section{References}

Damayanti, S. (2017). The Application of Lesson Study Activity in Palopo. Proceeding International Conference on Natural and Social Sciences (ICONSS) 20 I 7, Book I. http://journal.uncp.ac.id/index.php/iconss/article/view/496

Lewis, C., Perry, R., \& Murata, A. (2008). How Should Research Contribute to Instructional Improvement? The Case of Lesson Study. American Educational Research Association.

Brown, D.H. (2000). Principles of Language Learning and Teaching. Pearson Education Inc. 